\title{
De Vega tricuspid valve annuloplasty - a rightly neglected surgical technique?
}

\author{
Júlia Csanády, Vojtěch Kurfirst, Radim Frána, Aleš Mokráček \\ Department of Cardiac Surgery, Hospital České Budějovice, Czech Republic
}

Kardiochirurgia i Torakochirurgia Polska 2018; 15 (2): 95-101

\begin{abstract}
Introduction: There is a lot of discussion about the best surgical technique for tricuspid valve (TV) regurgitation in patients undergoing an operation for primary mitral valve disease.

Aim: To review and compare our results and experiences regarding the two main surgical strategies: tricuspid valve annuloplasty with a prosthetic ring (RING group) and suture annuloplasty (De Vega group).

Material and methods: We reviewed 570 patients who underwent TV surgery between 2000 and 2016 with either ring annuloplasty (RING group: $n=490(85.9 \%))$ or De Vega suture annuloplasty (De Vega group: $n=69(12.1 \%)$ ). The aetiology of TV insufficiency was secondary in $96.3 \%$ (538/559) of the patients, but $47.6 \%$ of the patients with primary aetiology had endocarditis of the permanent pacemaker stimulating wires. Results: The age of the two study groups was similar ( $p=$ 0.6589), with a mean age of 66.7 years for the ring annuloplasty group and 67.9 years for the De Vega suture technique. The overall 30-day mortality was $10.9 \%(n=61)$ (RING group $n=58(11.8 \%)$ and De Vega group $n=3(4.3 \%))$. Ten years after TV surgery with either ring annuloplasty or the De Vega suture technique, $5.8 \%$ of patients in both study groups presented with a recurrence of severe tricuspid regurgitation $\geq 3$.

Conclusions: Outcomes of tricuspid valve repair did not differ in terms of long-term stability and durability between the two evaluated techniques.
\end{abstract}

Key words: tricuspid regurgitation, De Vega suture annuloplasty.

\section{Introduction}

Secondary tricuspid regurgitation (TR) is common in patients with left-side valve disease, especially in the setting of severe pulmonary hypertension and atrial fibrillation $[1,2]$. Significant TR often does not regress after successful left-side valve surgery and can progress [3].

\section{Streszczenie}

Wstęp: Od wielu lat toczy się dyskusja, która technika chirurgiczna jest najlepsza w leczeniu niedomykalności zastawki trójdzielnej u pacjentów poddawanych zabiegom z powodu pierwotnej choroby zastawki mitralnej.

Cel: Przegląd i porównanie wyników i doświadczeń własnych związanych z dwiema głównymi strategiami chirurgicznymi annuloplastyką zastawki trójdzielnej z użyciem protezy pierścienia (grupa RING) i annuloplastyką z wykorzystaniem szwu (grupa De Vega).

Materiał i metody: Przeanalizowano dane 570 pacjentów poddanych w latach 2000-2016 annuloplastyce zastawki trójdzielnej z użyciem protezy pierścienia [grupa RING: $n=490$ (85,9\%)] lub szwu [grupa De Vega: $n=69$ (12,1\%)]. Etiologia niewydolności zastawki trójdzielnej była wtórna u 96,3\% pacjentów (538/559); jednak u 47,6\% pacjentów, u których choroba miała charakter pierwotny, wystąpiło zapalenie wsierdzia w obszarze stałych przewodów rozrusznika.

Wyniki: Wiek pacjentów w obu grupach był podobny ( $p=$ 0,6589): średni wiek w grupie RING wyniósł 66,7 roku, a w grupie de Vega - 67,9 roku. Śmiertelność całkowita w obserwacji 30-dniowej wyniosła 10,9\% $(n=61)$ [grupa RING: $n=58(11,8 \%)$; grupa De Vega: $n=3$ (4,3\%)]. Dziesięć lat po annuloplastyce zastawki trójdzielnej z użyciem pierścienia lub techniką szwową De Vegi nawrót ciężkiej niedomykalności zastawki trójdzielnej $\geq 3$ wystąpił u 5,8\% pacjentów w obu badanych grupach.

Wnioski: Wyniki naprawy zastawki trójdzielnej nie różniły się pomiędzy analizowanymi technikami pod względem długoterminowej stabilności i trwałości.

Słowa kluczowe: niedomykalność zastawki trójdzielnej, annuloplastyka szwowa De Vegi.

The 2014 AHA/ACC Guideline for the Management of Patients with Valvular Heart Disease recommended tricuspid valve surgery for patients with severe TR undergoing left-side valve surgery ( C). Tricuspid valve repair can be beneficial for patients with mild, moderate or greater functional TR at the time of left-side valve surgery with either:

Address for correspondence: Júlia Csanády MD, Department of Cardiac Surgery, Hospital, 54 Boženy Němcové St, 37001 České Budějovice, Czech Republic, phone: +42 0387874202, fax: +42 0387874201, e-mail: canadyova.julia@gmail.com

Received: 9.10.2017, accepted: 13.04.2018. 
1) tricuspid annular dilation or 2) prior evidence of right heart failure (Ila B) and may be considered for patients with moderate functional TR and pulmonary artery hypertension at the time of left-sided valve surgery (IIb C). Tricuspid valve surgery can be beneficial for patients with symptoms due to severe primary TR that are unresponsive to medical therapy (Ila C) and may be considered for asymptomatic or minimally symptomatic patients with severe primary TR and progressive degrees of moderate or greater RV dilation and/or systolic dysfunction (IIb C) [4].

Uncorrected, moderate or severe TR is associated with poor long-term survival and progressive heart failure [1]. However, the optimal surgical treatment to eliminate TR is still being debated. Secondary or functional tricuspid valve (TV) insufficiency is primarily treated by valve reconstruction, which carries a lower operative risk than valve replacement [5]. It is still unclear what type of annulus stabilization is more effective, prosthetic ring annuloplasty or suture-based De Vega annuloplasty. McCarthy et al. and several other authors have reported better long-term and event-free survival, freedom from recurrent TV regurgitation and reoperation in patients who underwent ring annuloplasty $[1,5,6]$. Others have reported excellent long-terms results using De Vega's technique [2, 5].

\section{Aim}

We examined our own experiences with TV repair using either modified De Vega suture or prosthetic ring annuloplasty with Carpentier-Edwards rings, with observations on long-term survival, incidence of TV regurgitation recurrence and frequency of reoperation due to failure of repair.

\section{Material and methods}

A total of 570 patients underwent TV surgery at the Department of Cardiac Surgery, Hospital of České Budějovice, Czech Republic, between January 2000 and December 2016. The study population consisted of 559 patients who underwent TV annuloplasty with either modified De Vega suture (De Vega group, $n=69(12.1 \%)$ ) or prosthetic ring annuloplasty (RING group, $n=490(85.9 \%)$ ); $11(2 \%)$ patients who underwent tricuspid valve replacement were excluded from the study (Table I).

The type of tricuspid valve repair was determined by surgeons' preference. De Vega annuloplasty was performed in patients with minimal annular dilation and lower severity of pulmonary hypertension. In cases of severe tricuspid ring dilatation and more severe pulmonary hypertension, ring annuloplasty was chosen.

The mean age at the time of surgery was $66.9 \pm 10.3$ (range: $15-88$ years) and did not differ between the groups ( $p=0.6758$ ), and was $67.9 \pm 8.6$ (range: $45-83$ years) for the De Vega group and $66.7 \pm 10.5$ (range: $15-88$ years) for the RING group. The patients comprised 245 (43.8\%) men and 314 (56.2\%) women (Table I).

A total of 538 (96.2\%) patients presented with functional TV regurgitation secondary to annular dilatation. The rest $(n=21)$ showed an organic aetiology, and $47.6 \%$ of patients with primary aetiology had endocarditis of the permanent pacemaker pacing wires.

Preoperative TR was severe in 136 (24.3\%), moderate in 386 (69\%) and minimal in 37 (6.7\%) patients with significant tricuspid annulus dilatation at the time of left-side valve surgery.

Preoperative pulmonary hypertension $(\mathrm{PH})$ was mild in 190 (32.6\%), moderate in 182 (20.8\%) and severe in 116 (12.7\%) patients, while no $\mathrm{PH}$ occurred in 71 (33.9\%) patients (Tables II-IV).

Doppler echocardiography is an important tool in our approach to assess and quantify the degree of pulmonary hypertension (Table II). An indirect indicator is the acceleration time of pulmonary artery flow, reflecting the impedance of the pulmonary fluid. Pulmonary pressures can be estimated from velocity measurements and gradient calculations for pulmonary and tricuspid regurgitation. The right atrial pressure is judged by the diameter and respiratory variation of the lower vena cava. Prognostically unfavourable echocardiography signs include dilatation of the right atrium and the presence of pericardial effusion.

The average preoperative New York Heart Association (NYHA) functional class was $2.2 \pm 0.7079$. Twenty-eight (5\%)

Table I. Preoperative characteristics of 559 patients who underwent TV repair with either ring annuloplasty (RING group) or De Vega suture annuloplasty (De Vega group)

\begin{tabular}{|c|c|c|c|c|}
\hline Parameter & All $(N=559)$ & $\begin{array}{l}\text { RING group } \\
(n=490)\end{array}$ & $\begin{array}{l}\text { De Vega group } \\
\quad(n=69)\end{array}$ & $P$-value \\
\hline Age, mean \pm SD [years] & $66.9 \pm 10.3$ & $66.7 \pm 10.5$ & $67.9 \pm 8.6$ & 0.6758 \\
\hline Female gender, $n / \%$ & $314 / 56.2$ & $271 / 55.3$ & $43 / 62.3$ & 0.3012 \\
\hline LVEF, mean \pm SD & $56.08 \pm 9.8$ & $58.3 \pm 9.7$ & $58.04 \pm 11.05$ & 0.0094 \\
\hline No sinus rhythm, $n / \%$ & $169 / 30.2$ & $143 / 29.2$ & $26 / 37.7$ & 0.1624 \\
\hline $\mathrm{NYHA} \geq \mathrm{III}, n / \%$ & $163 / 29.2$ & $136 / 27.8$ & $27 / 39.1$ & 0.0652 \\
\hline $\mathrm{PH}$, mean $\pm \mathrm{SD}$ & $1.6 \pm 0.9$ & $1.7 \pm 0.9$ & $0.9 \pm 1.1$ & $<0.0001$ \\
\hline
\end{tabular}

$\mathrm{PH}$ - pulmonary hypertension (0 no PH, 1 mild, 2 moderate, 3 severe), LVEF - left ventricle ejection fraction. 
patients were in class I, 368 (65.8\%) in class II, 148 (26.5\%) in class III and 15 (2.7\%) in class IV (Tables I, V).

Three hundred and ninety (69.8\%) patients presented with sinus rhythm, 169 (30.2\%) with atrial fibrillation, and no patients had a previously implanted permanent pacemaker (Table I).

Only $6.6 \%$ of the patients ( $n=37$ ) had undergone isolated surgery on the tricuspid valve, while $93.4 \%$ of the patients $(n=522)$ had undergone concomitant mitral/aortic valve surgery and coronary artery bypass grafting.

\section{Operative data}

In all, 599 patients underwent TV repair with either modified De Vega suture (De Vega group, $n=69(12.1 \%)$ ) or prosthetic ring annuloplasty (RING group, $n=490$ (85.9\%)). De Vega annuloplasty was performed using a 3.0 polypropylene running suture with multiple Teflon pledgets not only at the anteroseptal and posteroseptal commissures, but with every annular bite of the suture, extended to the right edge of the trigonum fibrosum to a point opposite the coronary sinus. The annuloplasty is completed by reversing the suture and interpositioning new pledgets with those implanted previously (Fig. 1).

Post-operative reduction of the annulus was achieved by suturing the stitch on the Hegar's dilator of the appropriate diameter of the tricuspid valve orifice. TV repair was performed if the anteroposterior ring size of the preoperative transthoracic echocardiography (TTE)/transesophageal echocardiography (TEE) $\geq 25 \mathrm{~mm} / \mathrm{m}^{2}$ in order to achieve

Table II. The degree of severity of pulmonary hypertension

\begin{tabular}{lcc} 
Degree & $\begin{array}{c}\text { Mean pulmonary pressure } \\
{[\mathrm{mm} \mathrm{Hg}]}\end{array}$ & $\begin{array}{c}\text { Systolic pulmonary } \\
\text { pressure }[\mathrm{mm} \mathrm{Hg}]\end{array}$ \\
Mild & $26-35$ & $36-45$ \\
\hline Moderate & $36-45$ & $46-60$ \\
\hline Severe & $>45$ & $>60$ \\
\hline
\end{tabular}

Table III. Preoperative distribution of pulmonary hypertension (PH) of 559 patients who underwent TV repair with either ring annuloplasty (RING group) or De Vega suture annuloplasty (De Vega group)

\begin{tabular}{|c|c|c|c|c|c|c|c|}
\hline \multirow[t]{2}{*}{ PH before TV repair } & \multicolumn{2}{|c|}{ All $(N=559)$} & \multicolumn{2}{|c|}{ RING group $(n=490)$} & \multicolumn{2}{|c|}{ De Vega group $(n=69)$} & \multirow[t]{2}{*}{$P$-value } \\
\hline & $n$ & $\%$ & $n$ & $\%$ & $n$ & $\%$ & \\
\hline Mild PH & 190 & 32.6 & 174 & 35.5 & 16 & 23.2 & 0.0566 \\
\hline Moderate $\mathrm{PH}$ & 182 & 20.8 & 176 & 35.9 & 6 & 8.7 & $<0.0001$ \\
\hline Severe PH & 116 & 12.7 & 105 & 21.5 & 11 & 15.9 & 0.3434 \\
\hline No PH & 71 & 33.9 & 35 & 7.1 & 36 & 52.2 & $<0.0001$ \\
\hline
\end{tabular}

$\mathrm{PH}$ - pulmonary hypertension, TV - tricuspid valve.

Table IV. Preoperative distribution of pulmonary hypertension (PH) and differences between the severities of PH in patients undergoing repair with either ring annuloplasty (RING group) or De Vega suture annuloplasty (De Vega group)

\begin{tabular}{|c|c|c|c|c|}
\hline PH RING vs. De Vega & Relative risk & $95 \%$ confidence interval & Odds ratio & $P$-value \\
\hline Mild PH & 1.531 & $0.9805-2.392$ & 1.824 & 0.0566 \\
\hline Moderate PH & 4.131 & $1.905-8.956$ & 5.885 & $<0.0001$ \\
\hline Severe $\mathrm{PH}$ & 1.344 & $0.7618-2.372$ & 1.438 & 0.3434 \\
\hline No PH & 0.1369 & $0.09258-0.2024$ & 0.07051 & $<0.0001$ \\
\hline
\end{tabular}

$\mathrm{PH}-$ pulmonary hypertension.

Table V. Number and percent of patients in each New York Heart Association (NYHA) functional class at time of follow-up

\begin{tabular}{|c|c|c|c|c|c|c|c|c|c|c|c|c|c|c|c|c|}
\hline \multirow[t]{3}{*}{ NYHA } & \multicolumn{4}{|c|}{ Before TV repair } & \multicolumn{4}{|c|}{1 year after TV repair } & \multicolumn{4}{|c|}{5 years after TV repair } & \multicolumn{4}{|c|}{10 years after TV repair } \\
\hline & \multicolumn{2}{|c|}{$\begin{array}{c}\text { Ring } \\
(n=490)\end{array}$} & \multicolumn{2}{|c|}{$\begin{array}{l}\text { De Vega } \\
(n=69)\end{array}$} & \multicolumn{2}{|c|}{$\begin{array}{c}\text { Ring } \\
(n=286)\end{array}$} & \multicolumn{2}{|c|}{$\begin{array}{l}\text { De Vega } \\
(n=34)\end{array}$} & \multicolumn{2}{|c|}{$\begin{array}{c}\text { Ring } \\
(n=197)\end{array}$} & \multicolumn{2}{|c|}{$\begin{array}{l}\text { De Vega } \\
(n=15)\end{array}$} & \multicolumn{2}{|c|}{$\begin{array}{c}\text { Ring } \\
(n=51)\end{array}$} & \multicolumn{2}{|c|}{$\begin{array}{c}\text { De Vega } \\
(n=8)\end{array}$} \\
\hline & $n$ & $\%$ & $n$ & $\%$ & $n$ & $\%$ & $n$ & $\%$ & $n$ & $\%$ & $n$ & $\%$ & $n$ & $\%$ & $n$ & $\%$ \\
\hline I & 26 & 5.3 & 2 & 2.9 & 147 & 51.4 & 20 & 58.8 & 87 & 44.2 & 8 & 53.3 & 28 & 54.9 & 4 & 50 \\
\hline II & 328 & 66.9 & 40 & 58 & 107 & 37.4 & 11 & 32.4 & 78 & 39.6 & 2 & 13.3 & 13 & 25.5 & 3 & 37.5 \\
\hline III & 125 & 25.5 & 23 & 33.3 & 32 & 11.2 & 3 & 8.8 & 32 & 16.2 & 4 & 26.7 & 10 & 19.6 & 1 & 12.5 \\
\hline IV & 11 & 2.3 & 4 & 5.8 & & & & & & & 1 & 6.7 & & & & \\
\hline
\end{tabular}

NYHA - New York Heart Association functional class. 

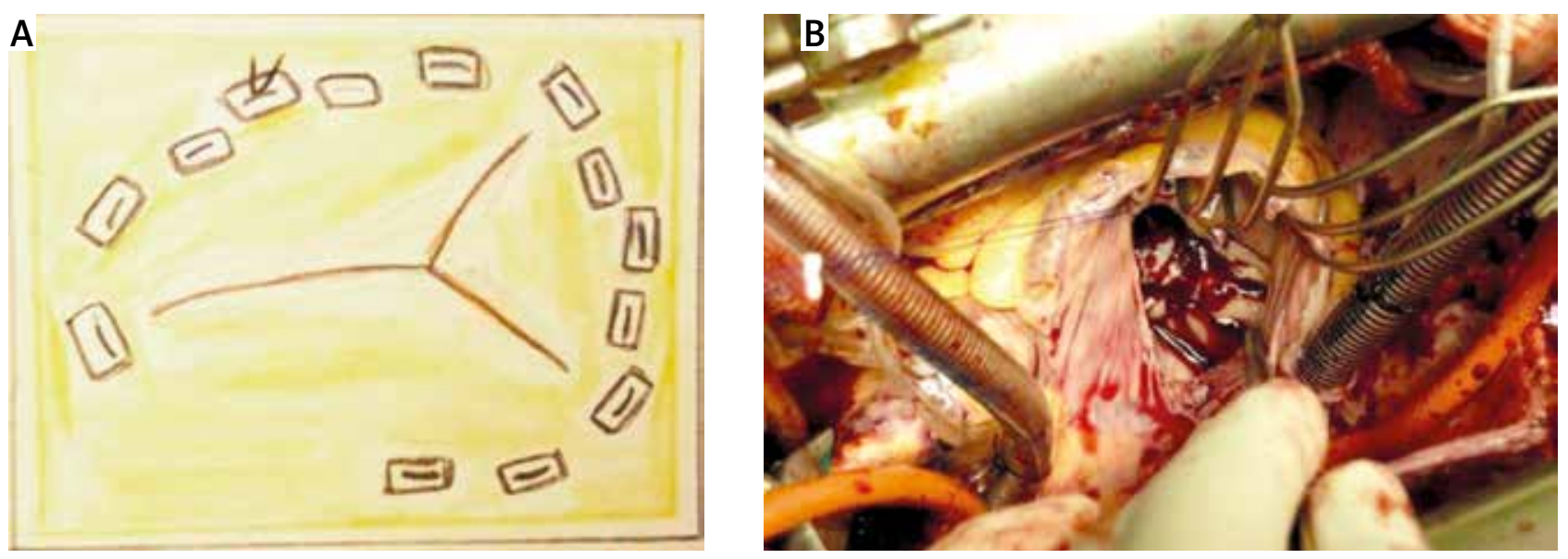

Fig. 1. The modified technique of DeVega annuloplasty

Table VI. Operative data of 559 patients who underwent TV repair with either ring annuloplasty (RING group) or De Vega suture annuloplasty (De Vega group)

\begin{tabular}{|c|c|c|c|c|}
\hline Variable & All $(N=559)$ & RING group $(n=490)$ & De Vega group $(n=69)$ & $P$-value \\
\hline Isolated TV surgery & $37(6.6 \%)$ & 35 (7.1\%) & $2(2.9 \%)$ & 0.2969 \\
\hline Concomitant procedure & $522(93.4 \%)$ & 455 (92.8\%) & 67 (97.1\%) & 0.2969 \\
\hline 2-valve surgery & $506(90.5 \%)$ & $452(92.2 \%)$ & $54(78.3 \%)$ & 0.6288 \\
\hline 3-valve surgery & $16(2.9 \%)$ & $3(0.6 \%)$ & $13(18.8 \%)$ & $<0.0001$ \\
\hline CBP time [min] & $111 \pm 40.05$ & $111.5 \pm 40.4$ & $108.8 \pm 37.8$ & 0.4695 \\
\hline Cross-clamp time [min] & $79.6 \pm 34.9$ & $79.2 \pm 35.6$ & $82.2 \pm 30.8$ & 0.6266 \\
\hline
\end{tabular}

CBP - cardiopulmonary bypass time, TV - tricuspid valve.

a postoperative reduction of approximately $16-18 \mathrm{~mm} / \mathrm{m}^{2}$ in the anteroposterior dimension.

A total of 490 patients received a Carpentier-Edwards ring (Edwards Lifesciences, Irvine, CA, USA). The appropriate size of the ring was selected based on the area of the anterior leaflet, and the length of the base of the tricuspid septal leaflet was measured using standard CarpentierEdwards ring sizers.

All patients were operated on through a full median sternotomy. Intraoperative myocardial protection was provided by antegrade cool blood cardioplegia into the aortic root. The mean cardiopulmonary bypass (CBP) time was $111.1 \pm 40.05 \mathrm{~min}$ and did not differ between the study groups $(p=0.4695)$. The mean aortic cross clamp time was $79.6 \pm 34.9 \mathrm{~min}$ and also did not differ between the study groups $(p=0.6266)$. Thirty-seven $(6.6 \%)$ patients had isolated TV repair, and 522 (93.4\%) patients underwent concomitant procedures, such as mitral and aortic valve surgery or coronary artery bypass grafting; 506 (90.5\%) patients underwent double valve surgery (tricuspid valve and mitral or aortic valve). Three-valve surgery (tricuspid valve and mitral and aortic valve surgery) was performed on $16(2.9 \%)$ patients (Table VI).

\section{Statistical analysis}

Simple descriptive statistics were used to summarize the data. Continuous variables are presented as the mean \pm standard deviation. Normality of the distributions was assessed using the D'Agostino-Pearson omnibus K2 tests and the ShapiroWilk normality test. Categorical variables were described as numbers and percentages (\%) and analysed using the $\chi^{2}$ test or Fisher's exact test, as appropriate. A confidence level of $95 \%$ was accepted as significant.

A non-parametric Mann-Whitney test was used to compare and study the relationships between the continuous variables. Survival curves for time-to-event variables were constructed on the basis of all available follow-up data using Kaplan-Meier estimates and were compared using the log rank test. A two-sided $\alpha$ level of 0.05 was used for all superiority testing. A $p$-value $<0.05$ was considered to be significant. The statistical analysis was performed using MS Excel 2003 for Windows XP and the GraphPad Prism version 5.01 statistical analysis software (Graph-Pad Software, Inc., San Diego, California, USA).

\section{Results}

Patients from both study groups were similar in age: $66.7 \pm 10.5$ vs. $67.9 \pm 8.6$ years, $p=0.6758$ (RING group vs. 
Table VII. Trend of postoperative New York Heart Association (NYHA) functional class $\geq$ III according to repair technique

\begin{tabular}{lcccc} 
NYHA $\geq$ III & Relative risk & $95 \%$ confidence interval & Odds ratio & $P$-value \\
Before RING vs. De Vega & 0.7093 & $0.5114-0.9839$ & 0.5976 & 0.0652 \\
\hline 1 year after RING vs. De Vega & 1.268 & $0.4100-3.922$ & 1.302 & 1.0000 \\
\hline 5 years RING vs. De Vega & 0.3865 & $0.1925-0.7760$ & 0.2743 & 0.0261 \\
\hline 10 years RING vs. De Vega & 1.569 & $0.2308-10.66$ & 1.707 & 1.0000 \\
\hline
\end{tabular}

NYHA - New York Heart Association functional class.

De Vega group). No significant differences were found between the 2 patient groups regarding gender distribution (female gender $55.3 \%$ vs. $62.3 \%, p=0.6758$, RING group vs. De Vega group) or preoperative atrial fibrillation occurrence $(29.2 \%$ vs. $37.7 \%, p=0.1624$, RING group vs. De Vega group). Patients in the RING group showed better preoperative left ventricular function ( $60 \%$ vs. $55 \%, p=0.0094)$. Preoperative pulmonary hypertension $(\mathrm{PH})$ in the RING group was mild in 174 (35.5\%) patients, moderate in 176 (35.9\%) and severe in 105 (21.5\%) patients, and no $\mathrm{PH}$ occurred in 35 (7.1\%) patients. Preoperative distribution of $\mathrm{PH}$ in the De Vega group was mild in 16 (23.2\%) patients, moderate in 6 (8.7\%) and severe in 11 (15.9\%), and 36 (52.2\%) patients had no PH (Tables III, IV). The occurrence of moderate $\mathrm{PH}$ was significantly higher in the RING group than in the De Vega group (35.9\% vs. 8.7\%, $p<0.0001$ ) (Tables I, III, IV).

Twenty-one (3.8\%) patients presented with primary aetiology of tricuspid valve regurgitation (17 vs. 4 patients, $p=0.3131$, RING group vs. De Vega group), including traumatic rupture, myxoma and infective endocarditis of permanent pacemaker pacing wires in 10 (47.6\%) patients. Concomitant procedures were performed with a similar frequency in both groups (92.8\% vs. $97.1 \%, p=0.2969$, RING group vs. De Vega group).

Determination of NYHA functional class showed an improvement compared with preoperative functional status between the patient groups during the follow-up (Table V). The prevalence of NYHA $\geq \mathrm{III}$ at 1,5 and 10 years after TV repair was $11.2 \%, 16.2 \%$ and $19.6 \%$ for the RING group and $8.8 \%, 33.4 \%$ and $12.5 \%$ for the De Vega group, respectively (Table VII). The difference in incidence of NYHA $\geq$ III between the study groups was significant 5 years after TV surgery $(p=0.0261)$ (Table $\mathrm{VI})$.

During the follow-up we also assessed the change in tricuspid regurgitation (TR) over time.

The prevalence of $3+$ or $4+$ tricuspid regurgitation at 1, 3, 5 and 10 years was $0.76 \%, 3.36 \%, 3.8 \%$ and $5.8 \%$ for the RING group and $0 \%, 0 \%, 6.8 \%$ and $5.8 \%$ for De Vega group, respectively. The difference in the trend of TR recurrence between the groups was not significant $(p=1.0000)$ (Fig. 2). The majority of the patients with severe TR did not undergo reoperation because of poor clinical status, as reoperation was considered to be of extremely high risk. More aggressive diuretic therapy was required.

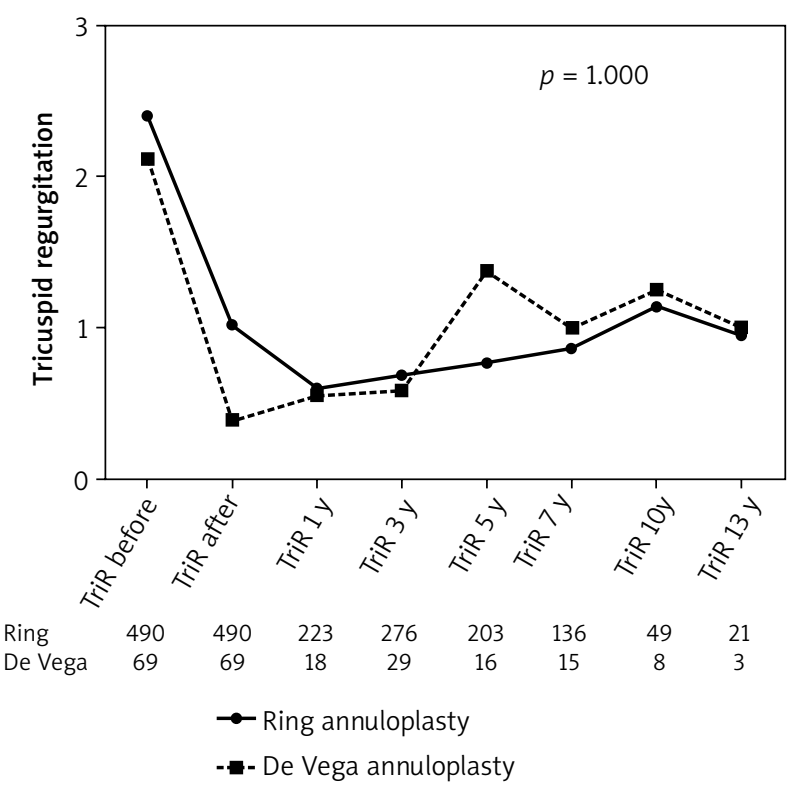

Fig. 2. Trend of postoperative tricuspid regurgitation grades after TV repair with either ring annuloplasty (RING group) or De Vega suture annuloplasty (De Vega group) during the follow-up

Tricuspid valve reoperations were performed in only 3 patients, and the initial tricuspid valve repair was ring annuloplasty in 2 patients and the De Vega suture method in 1 patient. In the 2 patients who underwent initial ring annuloplasty, the reason for the reoperation was suture dehiscence; 1 patient had TV replacement 2 years after the first operation, and the other patient received ring re-fixation 2 months postoperatively. One patient with previous De Vega suture repair had a tricuspid valve repair with a ring 22 years after the primary operation.

Overall, the 30-, 60- and 90-day mortality rates were 10.9 (61/559), 13.1 (73/559) and 14.5\% (81/559), respectively. Thirty-day mortality rates in the RING group and the De Vega group were $11.8 \%$ (58/490) and 4.3\% (3/69), respectively.

Ten-year survival after TV repair with ring annuloplasty or De Vega suture annuloplasty was $51.7 \%$ and $53.2 \%$, respectively ( $p=0.5259)$ (Fig. 3).

The 15-year survival rate after TV repair with ring annuloplasty or De Vega suture annuloplasty was $48.3 \%$ and $44.6 \%$, respectively. 


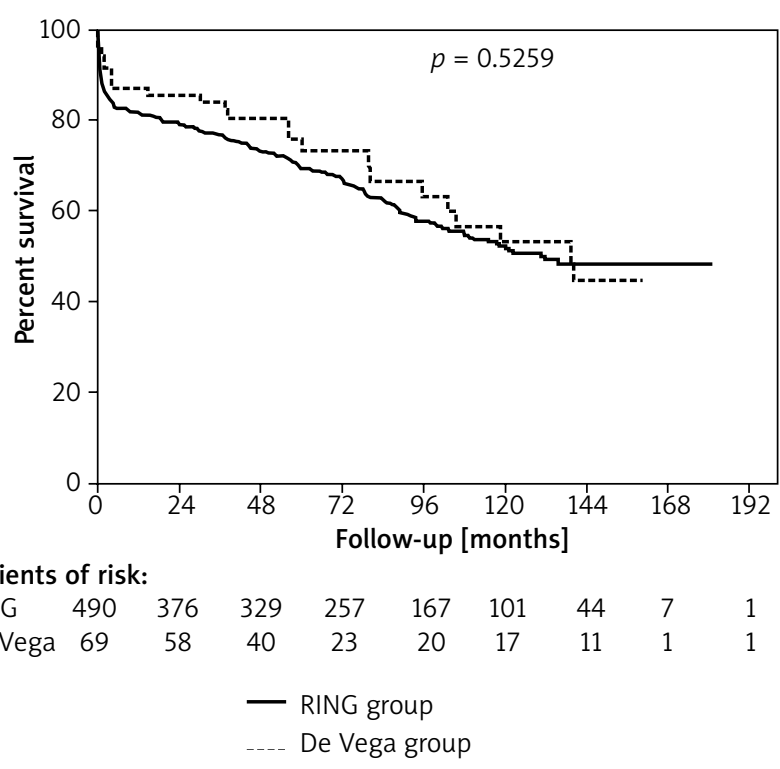

Fig. 3. Overall survival following TV repair with either ring annuloplasty (RING group) or De Vega suture annuloplasty (De Vega group)

\section{Discussion}

Secondary TR associated with left-side valve disease is a common finding. There is still a debate about the optimal treatment of functional TV regurgitation. For many years it was believed that secondary TR could disappear after mitral valve surgery alone, and consequently, it was ignored. Thus, for example, Braunwald, Ross and Morrow in 1967 recommended conservative nonsurgical management of "functional" TR. In the 1980s it was observed that patients who had undergone successful mitral surgery sometimes returned years later with severe symptomatic TR. When these patients underwent reoperation, the mortality was high. More recently, compelling data have shown that surgically untreated secondary TR can persist or progress despite correction of the associated left-side lesion [1]. Uncorrected TR has been associated with poor survival and long-term outcomes of the patients [2,3]. There is still some controversy regarding the impact of suture versus ring annuloplasty on long-term freedom from TR and reoperation in patients undergoing concomitant mitral valve surgery and TV repair. However, freedom from reoperation may seriously underestimate the prevalence of residual or recurrent tricuspid regurgitation, because tricuspid valve reoperation is considered "high risk" and may not be offered [6]. The low rate of reoperation may be in part due to the perception that it is a high-risk procedure [6]. Some patients tolerate moderate grades of regurgitation with minimal symptoms, and a few tolerate severe regurgitation with mild symptoms [6]. Reoperation for tricuspid valve disease proved to be a high-risk procedure, as others have found; the observed in-hospital mortality of $37 \%$ makes this one of the highest-risk cardiac valve operations. A poor track record here may create a self-fulfilling prophecy: patients with recurrent severe tricuspid regurgitation undergo aggressive treatment with diuretics and medication and are referred to surgery only when they develop severe disabling symptoms, including hepatic and renal dysfunction [6].

Recent long-term studies suggest that ring annuloplasty is more durable than suture annuloplasty. Data from the surgical literature suggest that more than $85 \%$ of patients having a ring annuloplasty will be free from $2+$ or greater TR 10 years after surgery. A number of studies have reported high recurrence of TR after the De Vega technique, particularly in patients with severe tricuspid annular dilation or pulmonary hypertension [1].

McCarthy et al. from the Cleveland Clinic recommended abandoning the De Vega suture technique due to the common recurrence of TR on the basis of analysis of 790 patients who underwent TV annuloplasty for functional regurgitation between 1990 and 1999 [6]. Navia et al. [1] studied more than 2000 patients in the period from 1990 to 2008 with functional TR and reported a high recurrence rate of TR after TV repair. Within 3 months after surgery, $34 \%$ of the patients had moderate or severe regurgitation. The authors concluded that a rigid prosthetic ring provides early and sustained reduction of TR secondary to left-side valve disease without the need for an additional leaflet procedure [1].

Parolari et al. performed a meta-analysis of early and long-term outcomes after tricuspid repair to compare the results of suture-based versus prosthetic ring annuloplasty. There was an advantage in early but not in long-term survival when using the ring. Freedom from moderate TR was significantly better in patients with ring annuloplasty (78.9 $\pm 5.0 \%$ at 15 years vs. $60.0 \pm 4.2 \%$, log-rank $p=0.0107$ ). Ring annuloplasty is thus associated with better outcomes, being a protective factor for early mortality and long-term recurrence of TR after surgery [3].

Guenther et al. reviewed 717 patients who underwent TV repair with either ring annuloplasty or De Vega suture annuloplasty between 1975 and 2009. The 10-year survival rates after TV repair with either ring annuloplasty or De Vega annuloplasty were $46 \pm 7 \%$, and $39 \pm 3 \%(p=0.01)$, respectively, and freedom from reoperation after TV repair with the De Vega suture technique was 88\% compared with $98 \%$ after ring annuloplasty $(p=0.034)$. The authors concluded that TV repair with ring annuloplasty is associated with improved survival and a lower reoperation rate compared to suture annuloplasty [5].

Shinn et al. from the Mayo Clinic reported similar outcomes of concomitant TV repair during mitral valve surgery with de Vega suture annuloplasty and flexible ring annuloplasty [2].

Long-term mortality and recurrence of TR in patients who underwent suture and ring annuloplasty were similar in our study population. De Vega suture annuloplasty provides good and stable results. Ten years after surgery, $94.2 \%$ of patients, either in the RING group or the De Vega suture group, will be free from $T R \geq 3$. Only $5.8 \%$ of patients in both groups show recurrence of $T R \geq 3$. 
In a selected group of patients with a lower degree of annular dilatation and less severe pulmonary hypertension, in intravenous drug abusers, De Vega suture annuloplasty can be a good alternative to ring annuloplasty. Last but not least, the cost-effectiveness of suture-based De Vega annuloplasty may be an important factor, playing a role in comparing the methods. In our country the cost of Prolene suture is approximately 5 euro in comparison with 900 euro for a commercially available prosthetic tricuspid ring.

\section{Conclusions}

It is well accepted that for TV repair, prosthetic ring annuloplasty has better results than suture-based annuloplasty. In our experience with patients undergoing TV repair of functional TR, both annuloplasty techniques have good and stable results over time. De Vega suture annuloplasty can be performed simply and rapidly and at a low cost compared with commercially available rings. De Vega suture technique appears to be an effective and durable repair. This technique is simple, reproducible, less costly and could be considered in a selected group of patients.

\section{Disclosure}

Authors report no conflict of interest.

\section{References}

1. Navia JL, Nowicki ER, Blackstone EH, Brozzi NA, Nento DE, Atik F, Rajeswaran J, Gillinov AM, Svensson LG, Lytle BW. Surgical management of secondary tricuspid valve regurgitation: annulus, commissure, or leaflet procedure? J Thorac Cardiovasc Surg 2010; 139: 1473-1482.

2. Shinn SH, Dayan V, Schaff HV, Dearani JA, Joyce LD, Lahr B, Greason KL, Stulak JM, Daly RC. Outcomes of ring versus suture annuloplasty for tricuspid valve repair in patients undergoing mitral valve surgery. J Thorac Cardiovasc Surg 2016; 152: 406-415.

3. Parolari A, Barili F, Pilozzi A, Pacini D. Ring or suture annuloplasty for tricuspid regurgitation? A meta-analysis review. Ann Thorac Surg 2014; 98: 2255-2263.

4. Nishimura RA, Otto CM, Bonow RO, Carabello BA, Erwin JP $3^{\text {rd }}$, Guyton RA, O‘Gara PT, Ruiz CE, Skubas NJ, Sorajja P, Sundt TM $3^{\text {rd }}$, Thomas JD; American College of Cardiology/American Heart Association Task Force on Practice Guidelines. 2014 AHA/ACC Guideline for the management of patients with valvular heart disease: executive summary. J Am Coll Cardiol 2014; 63: 2438-2488.

5. Guenther T, Mazzitelli D, Noebauer C, Hettich I, Tassani-Prell P, Voss B, Lange R. Tricuspid valve repair: is ring annuloplasty superior? Eur J Cardiothorac Surg 2013; 43: 58-65.

6. McCarthy PM, Bhudia SK, Rajeswaran J, Hoercher KJ, Lytle BW, Cosgrove DM, Blackstone EH. Tricuspid valve repair: durability and risk factors for failure. J Thorac Cardiovasc Surg 2004; 127: 674-685. 